\title{
PENGARUH HARGA DAN CITRA TERHADAP \\ KEPUASAN KONSUMEN ANGKRINGAN \\ DI KELURAHAN SENDANGADI, MLATI, SLEMAN
}

\author{
Nenci Ferronica Apri Melinda \\ Fakultas Ekonomi Universitas Sarjanawiyata Tamansiswa Yogyakarta
}

\begin{abstract}
ABSTRAK
Penelitian ini bertujuan Untuk mengetahui apakah harga, dan citra, mempunyai pengaruh secara bersama-sama terhadap kepuasan konsumen angkringan di Kelurahan Sendangadi, Mlati Sleman. Untuk mengetahui apakah harga, dan citra mempunyai pengaruh secara sendiri-sendiri terhadap kepuasan konsumen angkringan di Kelurahan Sendangadi, Mlati Sleman

Variabel penelitian ini adalah harga, citra dan kepuasan konsumen. Populasi dalam penelitian ini yaitu masyarakat yang membeli makanan angkringan di Kelurahan Sendangadi, Mlati, Sleman. Sampel penelitian ini adalah sebagian dari masyarakat yang membeli makanan angkringan di Kelurahan Sendangadi, Mlati, Sleman. Sampel diambil dari sebagain pupulasi sejumlah 56 orang. Metode pengambilan sampel Aksidental. Metode pengambilan data menggunakan kuesioner. Teknik analisis yang digunakan adalah regresi linier berganda dengan taraf signifikansi 5\%.

Hasil penelitian menunjukkan Hasil analisis data dengan Analisis Regresi Berganda diperoleh persamaan regresi $\mathrm{Y}=0,451 \mathrm{X}_{1}+0,349 \mathrm{X}_{2}$. Harga mempunyai pengaruh positif dan signifikan terhadap kepuasan konsumen dengan tingkat $\alpha=5 \%$. Citra mempunyai pengaruh positif dan signifikan terhadap kepuasan konsumen dengan tingkat $\alpha=5 \%$. Harga dan citra mempunyai pengaruh positif dan signifikan secara simultan terhadap kepuasan konsumen dengan tingkat $\alpha=5 \%$. Kepuasan konsumen dipengaruhi harga dan citra sebesar $51,4 \%$, sedangkan sisanya sebesar $48,5 \%$ dipengaruhi variabel lain, yang tidak di jelaskan dalam penelitian ini.
\end{abstract}

\section{Kata Kunci : Harga, Citra dan Kepuasan Konsumen}

\section{PENDAHULUAN}

\section{Latar Belakang Masalah}

Angkringan adalah rumah makan yang kebanyakan tidak permanen yang hanya menggunakan gerobak dan tenda, dimana makanan khas yang dijual adalah nasi bungkus, aneka gorengan, lauk pauk dan minuman. Angkringan merupakan warung makan sederhana yang pelayananya secara tradisional, dan makanan dan minuman yang dijual biasanya juga makanan tradisional. Selama ini sebagian angkringan dikembangan secara modern dan permanen yang melayani anak-anak muda untuk nokrong yang dilengkapi fasilitas internet maupun makanan dan tempat yang dikelola secara modern.

Angkringan mempunyai image atau citra dimasyarakat memiliki produk yang murah jika dibandingkan dengan rumah makan lainnya. Harga merupakan salah satu strategi usaha untuk memenangkan persaingan, hal ini lebih-lebih bagi produk angkringan, untuk menarik konsumen 
maka angkringan menggunakan harga yangrelatifdapat dijangkau konsumen dibanding dengan harga produk lain yang sejenis, sehingga mampu mempengaruhi konsumen untuk memutuskan membeli produk tersebut.

Angkringan memiliki citra di masyarakat tentang makanan yang disediakan khas jawa, cocok untuk nongkrok bagi anak muda, makanan yang higienes, tempat yang mudah didapatkan di plosok-plosok desa. Citra merupakan gambaran secara umum atau persepsi yang dimiliki oleh masyarakat umum tentang suatu perusahaan, unit atau produk. Angkringan merupakan salah satu alternatif untuk membantu memenuhi kebutuhan makan bagi para konsumen dengan segera, mengingat hal tersebut maka pihak pengelola angkringan harus selalu berupaya untuk bisa melayani dan memuaskan konsumen dengan sebaikbaiknya. Dengan demikian untuk dapat mencapai tujuan tersebut, rumah makan perlu memberikan variasi makanan sesuai dengan selera konsumen. Konsumen akan melakukan pembelian atau datang ke rumah makan kembali yang mereka anggap menawarkan nilai tambah yang tertinggi. Nilai yang diterima konsumen semakin besar apabila dilakukan: memperbaiki manfaat produk, pelayanan, mengurangi biaya moneter produk kepada pembeli, mengurangi biaya non moneter pembeli dengan memperkecil biaya waktu, tenaga dan pikiran pembeli (Kotler, 2003:98)

Terciptanya kepuasan pelanggan dapat memberikan beberapa manfaat, diantaranya hubungan antara perusahaan dan para pelanggannya menjadi harmonis, memberikan dasar yang baik bagi pembelian ulang, dapat mendorong terciptanya loyalitas pelanggan, membentuk suatu rekomendasi dari mulut ke mulut (word-of-mouth) yang menguntungkan bagi perusahaan, reputasi perusahaan menjadi baik di mata pelanggan dan pada akhirnya laba yang di peroleh dapat meningkat (Tjiptono, 2008:78).

Ditinjau dari segi ekonomi bahwa angkringan ini akan memberikan laba yang besar bagi pemilik angkringan dan memberikan dampak positif bagi masyarakat, karena dengan adanya angkringan akan membantu masyarakat dalam memenuhi kebutuhan makan dengan cepat dan mudah, namun semua ini perlu adannya suatu pengelolaan yang baik agar usahannya bisa berhasil dengan baik.

\section{Rumusan Masalah}

Berdasarkan uraian latar belakang masalah di atas, maka rumusan masalah penulisan skripsi ini adalah :

a. Apakah harga, dan citra, mempunyai pengaruh secara bersama-sama terhadap kepuasan konsumen angkringan di Kelurahan Sendangadi, Mlati Sleman?

b. Apakah harga, dan citra, mempunyai pengaruh secara parsial terhadap kepuasan konsumen angkringan di Kelurahan Sendangadi, Mlati Sleman?

\section{Kajian Teori}

Penganalisaan keinginan dan kebutuhan ditujukkan terutama untuk mengetahui adanya keinginan dan kebutuhan yang belum terpenuhi. Dengan memenuhi kualitas suatu produk atau jasa, maka diharapakan akan terpenuhi kepuasan konsumen. Kualitas yang merupakan konsep untuk dipahami, tidak jelas, dan sulit untuk diukur, terutama bagi jasa. Ketika membeli barang, konsumen dapat menilai kualitas barang dari banyak hal yang tampak mata seperti warna, mode, label, kemasan, dan rasa (Supranto, 1997:98).

Terciptanya kepuasan konsumen dapat memberikan beberapa manfaat, diantaranya hubungan antar perusahaan dan konsumen menjadi harmonis, memberikan dasar yang baik bagi pemakai/pembeli ulang dan terciptanya loyalitas konsumen, dan membentuk suatu rekomendasi dari mulut ke mulut 
yang menguntungkan bagi perusahaan. Ada beberapa pakar yang memberikan definisi mengenai kepuasan/ketidakpuasan konsumen (Kotler, 2003:136).

Kepuasan konsumen dapat ditarik kesimpulan bahwa pada dasarnya kepuasan konsumen mencakup perbedaan antara harapan dan kinerja atau hasil yang dirasakan. Karena konsumen adalah orang yang menerima hasil pekerjaan seseorang atau suatu organisasi, maka hanya merekalah akan menentukan kualitasnya seperti apa dan hanya mereka yang dapat menyampaikan apa dan bagaimana kebutuhan mereka. Hal inilah yang menyebabkan slogan gerakan kualitas yang populer berbunyi "kualitas dimulai dari konsumen ." Setiap orang dalam perusahaan harus bekerja dengan konsumen internal dan eksternal untuk menentukan kebutuhan mereka, dan bekerjasama dengan pemasok internal dan eksternal.

Harga adalah jumlah uang yang harus dibayar pelanggan untuk memperoleh produk tersebut. Harga adalah satu-satunya unsur bauran pemasaran yang menghasilkan pendapatan penjualan karena unsur yang lain adalah mengeluarkan biaya. Basu Swasta dan Ibnu Sukotjo (1998) : Harga adalah sejumlah uang (ditambah beberapa barang kalau mungkin) yang dibutuhkan untuk mendapatkan sejumlah kombinasi dari barang beserta pelayananya.

Menurut Tjiptono, (2008:84) harga mempunyai arti kesesuaian antara biaya yang dikeluarkan konsumen dengan kualitas produk yang diperoleh. Harga merupakan elemen bauran pemasaran yang menghasilkan pendapatan; semua elemen lainnya hanya mewakili harga. Harga dapat berubah dengan cepat. keputusan harga harus dihubungkan dengan keputusan rancangan produk, distribusi, dan promosi untuk membentuk program pemasaran yang efektif. Harga yang dibebankan perusahaan akan berada pada kisaran mulai dari terlalu rendah untuk menciptakan laba sampai terlalu tinggi untuk menimbulkan permintaan.

Citra berkaitan dengan reputasi sebuah merek/perusahaan. Citra adalah persepsi konsumen tentang kualitas yang berkaitan dengan merek/nama perusahaan. Citra itu sendiri bersifat abstrak namun keberadaannya bisa dirasakan dari penilaian, baik semacam tanda respek atau rasa hormat dari publik atau masyarakat luas terhadap suatu produk, perusahaan atau individu. Pada tingkat perusahaan, citra perusahaan didefinisikan sebagai persepsi tentang sebuah organisasi yang terefleksi dalam ingatan pelanggan (Fatmawati, 2004:11). Citra disebut juga dengan image. Menurut Suhartanto dan Priyatiningsih (2004:6). Citra merupakan gambaran secara umum atau persepsi yang dimiliki oleh masyarakat umum tentang suatu perusahaan, unit atau produk.

Yanuarius (2005:21) menjelaskan apa yang merupakan citra dan apa yang bukan merupakan citra dimana citra tidak mendeskripsikan ciri atau kualitas individual, namun menggambarkan total kesan yang diciptakan oleh suatu entitas pada pikiran orang lain. Suatu citra tidak mengakar hanya pada data dan detail obyektif karena ia menjadi konfigurasi dari seluruh bidang obyek.

\section{METODE PENELITIAN}

1. Jenis penelitian

Jenis penelitian yang digunakan adalah kuantitatif yaitu jenis penelitian yang berwujud angka-angka yang bersifat statistik (Sugiyono, 2006:89),

2. Variabel Penelitian

Variabel penelitian ini adalah harga, citra dan kepuasan konsumen.

3. Populasi, Sampel dan Teknik Pengambilan Sampel

Populasi dalam penelitian ini yaitu masyarakat yang membeli makanan angkringan di Kelurahan Sendangadi, Mlati, Sleman. Sampel penelitian ini 


\section{JURNAL MANAJEMEN VOL 4 NO 1 JUNI 2014}

adalah sebagian dari masyarakat yang membeli makanan angkringan di Kelurahan Sendangadi, Mlati, Sleman. Sampel diambil dari sebagian pupulasi sejumlah 56 orang. Metode pengambilan sampel Aksidental.
4. Metode Pengumpulan Data

Metode pengambilan data menggunakan kuesioner.

5. Analisis Data

Teknik analisis yang digunakan adalah regresi linier berganda dengan taraf signifikansi 5\%.

\section{HASIL PENELITIAN DAN PEMBAHASAN}

\section{Deskriptif Variabel Penelitian}

\section{a. Harga}

Tabel 1

Data Variabel Harga

\begin{tabular}{|l|l|l|l|}
\hline S & Kategori & ah & Prosentase \\
\hline $5-9$ & Sangat Tidak Setuju & 0 & 0 \\
\hline$>9-13$ & Tidak Setuju & 0 & 0 \\
\hline$>13-17$ & Netral & 14 & $25,00 \%$ \\
\hline$>17-21$ & Setuju & 30 & $53,57 \%$ \\
\hline$>21-25$ & Sangat Setuju & 12 & $21,43 \%$ \\
\hline Jumlah & & 56 & $100 \%$ \\
\hline
\end{tabular}

Sumber : Data Primer Diolah, (2014)

Dari data di atas diketahui bahwa responden yang menyatakan setuju bahwa harga makanan Angkringan di Keluruhan Sedangadi terjangkau ada 30 responden atau 53,57\%, yang

menyatakan sangat setuju ada 12 responden atau 21,43\%, yang menyatakan netral ada 14 responden atau $25 \%$.

\section{b. Citra}

Tabel 2

Data Variabel Citra

\begin{tabular}{|l|l|l|l|}
\hline S & Kategori & ah & Prosentase \\
\hline $5-9$ & Sangat Tidak Setuju & 0 & 0 \\
\hline$>7-13$ & Tidak Setuju & 1 & $1,79 \%$ \\
\hline$>13-17$ & Netral & 10 & $17,86 \%$ \\
\hline$>17-21$ & Setuju & 35 & $62,5 \%$ \\
\hline$>21-25$ & Sangat Setuju & 10 & $17,86 \%$ \\
\hline Jumlah & 56 & $100 \%$ \\
\hline
\end{tabular}

Sumber : Data Primer Diolah, (2014)

Dari data di atas diketahui bahwa responden yang menyatakan setuju bahwa citra produk Angkringan di Keluruhan Sedangadi baik ada 35 responden atau $62,5 \%$ yang menyatakan sangat setuju ada 10 responden atau $17,86 \%$, yang menyatakan netral ada 10 responden atau $17,86 \%$ dan yang menyatakan tidak setuju ada 1 responden atau $1,79 \%$ 


\section{c. Kepuasan Konsumen}

Tabel 3

Data Kepuasan Konsumen

\begin{tabular}{|l|l|l|l|}
\hline & Kategori & ah & Prosentase \\
\hline$<100$ & Tidak Puas & 32 & $57,14 \%$ \\
\hline$\geq 100$ & Puas & 24 & $42,86 \%$ \\
\hline Jumlah & 56 & $100 \%$ \\
\hline
\end{tabular}

Sumber : Data Primer Diolah, (2014)

Dari tabel di atas diketahui responden yang menyatakan tidak puas terhadap produk Angkringan di Kelurahan Sendangadi sebanyak 32 responden atau $57,14 \%$, yang puas terhadap produk Angkringan di Kelurahan Sendangadi sebanyak 24 responden atau $42,86 \%$.

\section{Analisis Data}

\section{a. Persamaan Regresi berganda}

Berdasarkan hasil analisis data dengan menggunakan SPSS 18.00 for windows diperoleh persamaan regresi seperti pada tabel dibawah ini:

\section{Tabel 4}

Hasil Pengujian Regresi Berganda

\begin{tabular}{|c|c|c|c|c|c|c|}
\hline \multirow{2}{*}{\multicolumn{2}{|c|}{ Model }} & \multicolumn{2}{|c|}{$\begin{array}{l}\text { Unstandardized } \\
\text { Coefficients }\end{array}$} & \multirow{2}{*}{$\begin{array}{l}\text { Standardiz } \\
\text { ed } \\
\text { Coefficient } \\
\mathrm{s} \\
\text { Beta }\end{array}$} & \multirow[b]{2}{*}{$\mathrm{t}$} & \multirow[b]{2}{*}{ Sig. } \\
\hline & & B & $\begin{array}{l}\text { Std. } \\
\text { Error }\end{array}$ & & & \\
\hline 1 & (Constant) & $\begin{array}{l}11,13 \\
7\end{array}$ & 11,485 & & ,970 & ,337 \\
\hline & Harga & 2,494 & 691 & 451 & 3,607 & ,001 \\
\hline & Citra & 2,064 & ,739 & ,349 & 2,792 &, 007 \\
\hline
\end{tabular}

Berdasarkan tabel diatas, maka dapat diperoleh persamaan regresi yaitu:

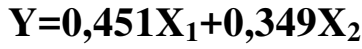

1) $b_{1}=0,451$

Koefisien harga positif berarti harga berpengaruh secara

b. Uji t

Analisis ini uji t dilakukan pada derajat kebebasan (n-k-1) = 54, dimana $\mathrm{n}$ adalah jumlah observasi dan $\mathrm{k}$ adalah jumlah positif terhadap kepuasan konsumen

2) $b_{2}=0,349$

Koefisien citra positif berarti citra berpengaruh secara positif terhadap kepuasan konsumen variabel. Dan pada tingkat keyakinan $95 \%$ atau $\alpha=5 \%$. 
Tabel 5

Hasil Uji t

\begin{tabular}{|ll|l|l|}
\hline \multicolumn{2}{|l|}{ Model } & \multicolumn{1}{l|}{} \\
& & $\mathrm{t}$ & Sig. \\
\hline 1 & (Constant) &, 970 &, 337 \\
& Harga & 3,607 &, 001 \\
& Citra & 2,792 &, 007 \\
\hline
\end{tabular}

Dari hasil oleh data di atas diketahui t-hitung masing masing variabel adalah

1) Variabel harga t-hitung lebih besar dari t-tabel $(3,607>$ 1,9847) dengan probabilitas $(0,001)$ lebih kecil dari taraf signifikan 0,05 , dengan demikian Ho ditolak dan $\mathrm{Ha}$ diterima, artinya variabel harga mempunyai pengaruh

\section{c. Uji F}

Dalam analisis ini, uji $\mathrm{F}$ dilakukan pada tingkat keyakinan 95\% atau $\alpha=5 \%$ dengan derajat kebebasan pembilang $\mathrm{k}-1$, yaitu 1 dan derajat kebebasan penyebut $\mathrm{n}-\mathrm{k}-1$, yaitu 54 atau dapat dituliskan dengan $\mathrm{F} 0,05$; df (1;54). Untuk pengujian koefisien regresi variabel independen berpengaruh positif dan signifikan terhadap variabel dependen secara bersama-sama, maka terlebih dahulu ditentukan hipotesis nol (Ho) dan hipotesis alternatif (Ha) sebagai berikut yang signifikan terhadap kepuasan konsumen.

2) Variabel citra t-hitung lebih besar dari t-tabel $(2,792>$ $1,9847)$ dengan probabilitas $(0,007)$ lebih kecil dari taraf signifikan 0,05, dengan demikian Ho ditolak dan $\mathrm{Ha}$ diterima, artinya variabel citra mempunyai pengaruh yang signifikan terhadap kepuasan konsumen.

Ho : tidak ada pengaruh yang signifikan secara simultan antara variabel harga dan citra terhadap kepuasan konsumen.

$\mathrm{Ha}$ : ada pengaruh yang signifikan secara simultan antara variabel harga dan citra terhadap kepuasan konsumen

Dengan taraf nyata $5 \%$ dimana $\mathrm{n}=56, \mathrm{k}=2$

F-tabel : F 0,05; df (k-1; n-k-1) F-tabel : F 0,05 ; df $(1 ; 54)=$ 2,4685

Tabel 6

Hasil Nilai Uji-F

\begin{tabular}{|ll|l|l|l|l|l|}
\hline \multicolumn{2}{|l|}{ Model } & $\begin{array}{l}\text { Sum of } \\
\text { Squares }\end{array}$ & df & $\begin{array}{l}\text { Mean } \\
\text { Square }\end{array}$ & F & Sig. \\
\hline 1 & Regression & 5693,63 & 2 & 2846,8 & 30,064 &, $000^{a}$ \\
& 4 & 17 & & \\
& Residual & $\begin{array}{l}5018,58 \\
9\end{array}$ & 53 & 94,690 & & \\
& Total & 10712,2 & 55 & & & \\
& 23 & & & & \\
\hline
\end{tabular}

a. Predictors: (Constant), Citra, Harga

b. Dependent Variable: Kepuasan Konsumen 
Dari hasil pengolahan data di atas diketahui bahwa nilai Fhitung adalah 30,064. Dengan nilai signifikan sebesar 0,000 , dan nilai F-tabel adalah 2,4685. Dengan demikian dapat disimpulkan bahwa F-hitung $>$ F- tabel dengan tingkat signifikan $0,000<0,05(\mathrm{p}<0,05)$, maka Ho ditolak dan $\mathrm{Ha}$ diterima berarti variabel-variabel harga dan citra berpengaruh secara simultan terhadap kepuasan konsumen.

\section{d. Koefisien Determinasi}

\section{Tabel 7}

Hasil Analisis Koefisien Determinasi $\left(\mathbf{R}^{2}\right)$

\begin{tabular}{|c|c|c|c|c|}
\hline $\begin{array}{l}\text { Mode } \\
1\end{array}$ & $\mathrm{R}$ & R Square & $\begin{array}{l}\text { Adjusted } \\
\text { R Square }\end{array}$ & $\begin{array}{l}\text { Std. Error } \\
\text { of the } \\
\text { Estimate }\end{array}$ \\
\hline 1 & $.729(a)$ & .532 & .514 & 9.73090 \\
\hline
\end{tabular}

Dari perhitungan di atas diperoleh nilai Adjusted $\mathrm{R}^{2}=$ 0,514 atau 51,4\%, hal ini menunjukkan bahwa variasi kepuasan konsumen (Y) yang dapat dijelaskan variabel harga dan citra sebesar 51,4\%. Sedangkan sisanya sebesar $48,5 \%$ dipengaruhi variabel lain.

\section{Pembahasan}

Hasil penelitian menunjukkan bahwa harga mempunyai pengaruh positif dan signifikan terhadap kepuasan konsumen. Adanya pengaruh ini menunjukkan semakin terjangkau harga produk Angkringan di Kelurahan Sendangadi Mlati, Sleman, maka akan meningkatkan kepuasan konsumen. Sehingga apabila kesesuaian antara harga produk angkringan dengan kualitas makanan maupun perbandingannya dengan harga makanan rumah makan lain lebih murah, maka akan mendorong konsumen puas menggunakannya. Sesuai pendapat Tjiptono, (2008) yang menyatakan bawah harga yang sesuai dengan biaya yang dikeluarkan konsumen dengan kualitas produk yang diperoleh, maka akan meningkatkan kepuasan konsumen. Harga merupakan elemen bauran pemasaran yang menghasilkan pendapatan; semua elemen lainnya hanya mewakili harga. Harga dapat berubah dengan cepat yang, keputusan harga harus dihubungkan dengan keputusan rancangan produk, distribusi, dan promosi untuk membentuk program pemasaran yang efektif. Harga yang dibebankan perusahaan akan berada pada kisaran mulai dari terlalu rendah untuk menciptakan laba sampai terlalu tinggi untuk menimbulkan permintaan, yang pada akhirnya adalah kepuasan konsumen.

Hasil penelitian menunjukkan bahwa citra mempunyai pengaruh positif dan signifikan terhadap kepuasan konsumen. Adanya pengaruh ini menunjukkan semakin baik citra produk Angkringan di Kelurahan Sendangadi Mlati, Sleman, maka akan meningkatkan kepuasan konsumen. Sehingga apabila image konsumen atas suatu produk Angkringan di Kelurahan Sendangadi, Mlati, Sleman berdasarkan produk yang khas, higienes, selera konsumen, dan tempat baik, maka akan mendorong konsumen puas menggunakannya. Sesuai pendapat Yanuarius (2005) 
citra yang efektif akan meningktkan kepuasan konsumen. Citra yang efektif dapat dilakukan dengan tigal hal yaitu pertama, menyampaikan satu pesan tunggal yang memantapkan karakter produk dan usulan nilai. Kedua, menyampaikan pesan tersebut dengan cara yang berbeda sehingga tidak dikelirukan dengan pesan serupa dari para pesaing. Sedangkan yang ketiga, mengirimkan kekuatan emosional sehingga membangkitkan hati maupun pikiran pembeli. Mengembangkan citra yang kuat membutuhkan kreativitas dan kerja keras karena citra tidak dapat ditanamkan dalam pikiran masyarakat dalam semalam atau disebarkan melalui satu media saja. Citra terbentuk dari dua faktor yaitu faktor komunikasi dan pengalaman konsumen selama mengonsumsi barang atau jasa yang mereka beli. Faktor komunikasi yang terbentuk antara suatu organisasi dengan publik baik berupa promosi seperti : brosur, poster maupun melalui media informasi seperti koran, televisi, majalah dan radio akan mempengaruhi persepsi pelanggan terhadap organisasi tersebut. Selain dipengaruhi oleh promosi dan komunikasi melalui media, persepsi pelanggan dipengaruhi oleh komunikasi diantara pelanggan dengan pelanggan yang lain.

Hasil penelitian menunjukkan bahwa harga dan citra mempunyai pengaruh positif dan signifikan secara simultan terhadap kepuasan konsumen. Adanya pengaruh ini menunjukkan semakin terjangkau produk angkringan dan semakin baik citra produk Angkringan di Kelurahan Sendangadi Mlati, Sleman, maka akan meningkatkan kepuasan konsumen. Sehingga apabila kesesuaian antara harga produk angkringan dengan kualitas makanan maupun perbandingannya dengan harga makanan rumah makan lain lebih murah dan image konsumen atas suatu produk Angkringan di Kelurahan Sendangadi, Mlati, Sleman berdasarkan produk yang khas, higienes, selera konsumen, dan tempat baik, maka akan mendorong konsumen puas menggunakannya. Kepuasan konsumen dipengaruhi harga dan citra sebesar 51,4\%, sedangkan sisanya sebesar $48,5 \%$ dipengaruhi variabel lain, yang tidak di jelaskan dalam penelitian ini.

\section{SIMPULAN}

Berdasarkan penelitian yang telah dilakukan diperoleh hasil-hasil sebagai berikut :

1. Hasil analisis data dengan Analisis Regresi Berganda diperoleh persamaan regresi $Y=11,137+0,451 X_{1}+0,349 X_{2}$

2. Harga mempunyai pengaruh positif dan signifikan terhadap kepuasan konsumen dengan tingkat $\alpha=5 \%$.

3. Citra mempunyai pengaruh positif dan signifikan terhadap kepuasan konsumen dengan tingkat $\alpha=5 \%$.

4. Harga dan citra mempunyai pengaruh positif dan signifikan secara simultan terhadap kepuasan konsumen dengan tingkat $\alpha=5 \%$.

5. Kepuasan konsumen dipengaruhi harga dan citra sebesar 51,4\%, sedangkan sisanya sebesar $48,5 \%$ dipengaruhi variabel lain, yang tidak di jelaskan dalam penelitian ini. 
DAFTAR PUSTAKA

Basu Swastha Dharmmesa dan Khusniyah Purwani (2002) dengan judul : Perilaku Beralih Merek Konsumen dalam Pembelian Produk Otomotif, Journal Ekonomi dan Bisnis Indonesia, Vol. 17 No. 3.

Basu Swastha Dharmmesta dan Ibnu Sukotjo (1998), Keputusan-Keputusan Stratejik untuk Mengeksplorasi Sikap dan Perilaku Konsumen, Jurnal Ekonomi dan Bisnis Indonesia, 12 : 1-19.

Fatmawati, Indah, (2004), Pengaruh Kualitas Pelayanan dan Nilai Pelayanan terhadap Loyalitas Pelanggan, Utilitas, Vol. 12, No. 1 A, April, h. 55- 67.

Kandampully dan Suhartanto (2000), Customer Loyalty in The Hotel Industry : The Role of Customer Satisfaction and Image, Journal of Contemporary Management, 12: 346-351.
Kotler, Philip, (2003), Marketing Management, $11^{\text {th }} \mathrm{ed}$, Upper Saddle River, New Jersey: Prentice Hall International, Inc.

Sugiyono, (2006), Metode Penelitian Bisnis, Alfabeta, Bandung.

Suhartanto dan Priyatiningsih (2004) dengan judul : Citra Supermarket, JSB.

Supranto, J. (1997), Pengukuran Tingkat Kepuasan Pelanggan Untuk Menaikkan Pangsa Pasar, Jakarta: PT. Rineka Cipta.

Tjiptono, Fandy, (2008), Prinsip-prinsip Total Quality Service, Edisi 2, Yogyakarta: Andi.

Yanuarius Sriyono (2005) dengan judul : Pengaruh Citra, Kualitas dan Kepuasan terhadap Loyalitas, Tesis, Yogyakarta. 